\title{
Fiscal Transfers, Horizontal Equity and Post-Secondary Education
}

\author{
DEREK HUM* and FRANK STRAIN†
}

\begin{abstract}
Fiscal Transfers, Horizontal Equity and Post-Secondary Education

Horizontal equity is interpreted to mean that equals in different provinces should be treated equally. We argue that current arrangements for government funding of post-secondary education in Canada are flawed because they contain provisions which perpetuate disparities in the treatment of Canadians by province of residence. Current arrangements are criticized for inadequate equalization and lack of expenditure standards. An education-needs adjustment factor is suggested.

Fiscal equity strives to ensure that citizens in all provinces have access to comparable services and bear comparable tax burdens. The cost of services is conditional on the expenditure standard selected and the number of beneficiaries. The capacity to provide the service is related to the population and wealth of the province. Accordingly, our suggested amendment incorporates all these elements; it allows greater fiscal transfers to provinces experiencing greater need and/or smaller tax bases.
\end{abstract}

\section{RÉSUMÉ}

Transferts fiscaux, égalité horizontale et éducation postsecondaire

Par «égalité horizontale», nous entendons le principe selon lequel tous les citoyens des différentes provinces ont droit aux mêmes égards face au gouvernement. Nous pensons que les moyens de financement actuels de l'éducation postsecondaire au Canada sont défectueux, puisqu'ils comprennent des clauses qui perpétuent les inégalités existantes entre les Canadiens d'après leur province d'origine. Nous en critiquons par ailleurs certaines disproportions relatives à la distribution des fonds ainsi que l'absence de critères régissant l'allocation de ces fonds. Il faut donc envisager un ajustement des dépenses qui respecte les besoins de chaque province en matière d'éducation. 
Le principe même de l'égalité fiscale suppose que les citoyens de toutes les provinces reçoivent les mêmes services et paient les mêmes impôts. Le coût des services dépend des critères choisis pour l'allocation des fonds et du nombre de bénéficiaires. La capacité d'assurer des services dépend de la population et de la richesse de chaque province. Ces divers éléments se retrouvent donc dans l'amendement que nous suggérons, à savoir que les transferts de capitaux soient plus importants vers les provinces qui ont les besoins les plus pressants ou vers celles dont les revenus sont les plus faibles.

\section{INTRODUCTION}

The principle of horizontal equity requires the equal treatment of equals. Equal treatment is particularly difficult whenever population is geographically dispersed such that the impact of social policies vary with place of residence; and even more so under a federal constitutional structure, when responsibility for the well being of citizens is divided between two orders of government. Consequently, the meaning of horizontal equity is less clear. Must equals in different provinces be treated equally when social programming is a provincial responsibility? If so, this would require some notion of national standards and imply that provincial wishes are subordinate somehow to national objectives. Or is it sufficient that equals within any province be treated equally? If social programming is exclusively within provincial jurisdiction, the implication is quite clear. Horizontal equity is only relevant when pursued by a government enjoying the requisite constitutional authority. Thus equals in different provinces need not be treated equally when social policy is purely a provincial responsibility. ${ }^{1}$

Horizontal equity also has implications for intergovernmental financial transfers and the interpretation of fiscal equity. Fiscal equity is taken to mean that citizens in all provinces should have access to comparable services and bear comparable tax burdens. But should service levels be compared with the most generously provided program? And are tax burdens to be gauged against the most wealthy province? How, if at all, do provincial needs affect fiscal equity and equalization?

In this paper we interpret horizontal equity to mean that equals in different provinces should be treated equally. This stance guides our analysis of federal-provincial fiscal arrangements for financing social policy, especially post-secondary education. We argue that current arrangements for governmental funding of post-secondary education (PSE) are fundamentally flawed because they contain provisions which result in disparities in the treatment of Canadians by province of residence. Canada recently reaffirmed that federal support of post-secondary education must serve two goals: (1) "the maintenance and development of a strong and effective post-secondary system across Canada" and (2) "access to such a system on the part of all qualified and interested Canadians" 
(Canada 1985, 58). It further stated that federal transfers are the major vehicle for achieving the former objective. Direct student aid programs are designed to achieve accessibility. Because the horizontal equity implications of direct student support programs are quite transparent, this paper confines itself to the less obvious horizontal equity aspects connected with fiscal transfers and the first of the two above federal goals in post-secondary education.

The next section discusses current financial arrangements for social policy in Canada and identifies major problems. We argue that the EPF (the program which finances hospital and medical insurance and post-secondary education) as well as the CAP (the program which finances general assistance and welfare services) share a common weakness; namely, the perpetuation of a fragmented welfare state in which not all Canadians are offered comparable treatment. The following section examines post-secondary education in more detail, and shows that current financial arrangements contribute to provincial disparities in access to postsecondary education. The final section comments on the recent reform proposals of the Johnson Report (1985) and the Macdonald Commission (1985) as well as presenting our own suggestion to achieve horizontal equity.

\section{The current system of fiscal arrangements}

The British North America Act, 1867, created a federation whereby the central government enjoys jurisdiction over national issues, and provincial governments have responsibility for local matters. The areas within provincial competence include: education, hospitals, administration of justice, licensing of business, property and civil rights, and matters of local or private concern. Since significant state involvement in social policy was not contemplated at the time of Confederation, the BNA Act contained few references to social welfare matters. Furthermore, subsequent judicial interpretation of the Act has confirmed provincial responsibility for most areas of social policy. Accordingly, the specific assignment of the BNA Act together with a tradition of private and municipal social delivery combined to produce a welfare state with few national programs and little consistency across the country (Hum 1983).

Beginning in the $1920 \mathrm{~s}$, the national government came under increasing pressure to assume a role in social policy. This pressure can be traced to two sources. First, the constitutional assignment of tax and spending powers resulted in fiscal imbalance. Provinces found themselves responsible for many expensive policy areas but lacking in ability to raise funds. They responded by petitioning Ottawa for increased financial resources. Second, Canadians were demanding more social programs and politicians in Ottawa had to heed electorial wishes in order to acquire or retain power.

The national government responded in three ways. The first response was to support provincial social policy through a conditional or cost sharing grant. The Old Age Pension Act of 1927, which committed the national government to reimburse provinces for payments to persons over 70 years of age, was the first 
such shared cost program in the social policy sphere. Since then shared-cost programs have proliferated to include: support for general social assistance and social services, medicare, hospital insurance, and post-secondary education. The second type of response was to negotiate amendments to the BNA Act. Constitutional amendments, such as those granting the national government competence to make laws governing Unemployment Insurance and the Canada Pension Plan, permanently altered the distribution of legislative powers, thereby enabling the national government to deliver certain programs. The final type of response was for the national government to provide direct payments to individuals, and to finance them out of general revenues. Family Allowances, Old Age Security, and the Guaranteed Income Supplement are examples of programs in which the central government makes direct payments to citizens.

With respect to education in particular, the period 1867 to 1912 saw little federal government involvement. Education was a local (Parish or municipal) responsibility and a relatively low cost area. Thus the earliest transfers, the statutory subsidies, were not motivated by concerns related to education. The only two important federal initiatives in education appear to be the establishment of the Royal Military College in 1876 and a gift, in the form of a 150,000 acre endowment, to the University of Manitoba.

Public pressure for federal involvement in education began to build just after the turn of the century. In 1910 the federal government appointed the Royal Commission on Industrial Training and Vocational Education. This Royal Commission left a mark on most federal initiatives in the period that followed.

The first conditional grant program in Canada was introduced in 1913 under the auspices of the Agricultural Instruction Act. The program was a response to demands for vocational training emanating from the agricultural community. Eggleton and Kraft (1939: 40) argued that the federal response was necessary because provincial governments did not have sufficient revenue to act alone. The grants were not matching. Thus, despite the absence of adjustments based on need or tax capacity, the program did not severely penalize poor provinces.

In 1919 the federal government introduced the Technical Education Act which committed the federal government to spend ten million dollars over a ten-year period on upgrading vocational training and industrial education. The grants were of the matching type - a fact which made it difficult for the poorer provinces to access available monies. When the Act lapsed in 1929, Ontario was the only province to have taken full advantage of the allotted funds. James Maxwell (1937) has argued that these grants not only favoured rich provinces but also induced poor provinces to engage in schemes beyond their fiscal strength.

As the end of the Technical Education Act neared, another Royal Commission to study vocational education was struck. This resulted in the Vocational Education Act of 1931. However, with the depression and the associated decline in revenue and rise in expenditures, the federal government was forced to rethink its involvement in education. The Vocational Education Act was never proclaimed despite the fact that it passed both Houses of Parliament. The Technical Education 
Act was given two extensions which prolonged its existence until 1939 (Parliamentary Task Force on Federal-Provincial Fiscal Arrangements 1981, 56).

The depression directed federal attention to another aspect of the education system: the absence of occupational skills among those leaving school. In an attempt to alleviate this problem the federal government introduced the Unemployment and Agricultural Assistance Act which contained provisions for conditional subsidies to support various occupational training projects. This Act was proclaimed in 1937 and was replaced in 1939 by the Youth Training Act.

Federal involvement in education in the years 1912 to 1939 reflected the work of the 1910 Royal Commission on Industrial Training and Vocational Education. The objectives were purely economic: the national economy required a continuing supply of skilled manpower to assure economic growth.

No program reflected concerns for equality of opportunity or horizontal equity. Indeed, the 50-50 cost sharing approach adopted in many programs of this period probably exacerbated educational disparities since only the rich provinces were in a position to take full advantage of the available monies and resources of the poor provinces were probably diverted from primary and secondary education into vocational training. Thus horizontal equity concerns were not the motivating factor in any of the early programs.

It is generally held that governments enjoy the right to make gifts; a right derived from the doctrine of Royal Prerogative and common law. Furthermore, conditions may be attached to these gifts or grants; individuals or government may refuse these gifts if they disagree with the conditions attached; but in any case such gifts do not violate any rules of constitutional jurisdiction. Quebec has always questioned the constitutionality of cost-shared schemes and direct transfers to individuals.

Elsewhere (Strain \& Hum 1987) we have argued that the history of the Canadian welfare state has been a gradual movement towards national social citizenship rights, and thus broad-based horizontal equity. However, we also noted that this evolution is incomplete, despite general equalization, which purports to adjust the overall fiscal capacity of the poorer provinces. National programs, whether direct transfer programs financed out of general revenue, (e.g., Old Age Security) or contributory social insurance programs made possible through constitutional amendment (e.g., Unemployment Insurance) are generally consistent with horizontal equity. But provincial programs such as social assistance or postsecondary education, which are partly financed through fiscal transfers, are not horizontally equitable. This is largely due to two fundamental flaws in the current system of intergovernmental transfers.

Both of these flaws can be found in the original design of the 1927 Old Age Pension Program. This program required the national government to reimburse the provinces $\$ .50$ for every $\$ 1.00$ spent on old age pensions: the so-called $50 / 50$ cost-sharing formula. But this arrangement penalizes provinces with limited fiscal resources. If a province does not have the financial wherewithal to introduce a program, it cannot be reimbursed for its nonexistent expenditure. Further, heavier 
burdens are imposed upon lower-income provinces which have programs because they have to levy heavier taxes to provide their share of the costs unless there is full general equalization. Uneven development of social programs will result. Indeed, it was 1936 before all provinces were even participating in the cost-shared Old Age Pension program.

The second design flaw is the absence of explicit national standards of any sort. This flaw was remedied in 1948 when the Old Age Pension Act was amended to ensure some measure of uniformity. However, in later programs, particularly CAP (Canada Assistance Plan) and EPF (Established Program Financing) this problem would re-emerge, and remains still.

Existence of these two flaws has been recognized for some time. The difficulties associated with achieving horizontal equity in the face of disparities in fiscal capacity were explicitly treated in the Rowell-Sirois Royal Commission Report in the late 1930s. The Rowell-Sirois Report recommended a system of National Adjustment Grants to remedy the problem. The National Adjustment Grant would enable all provinces to supply the average level of public services without having to impose rates of taxation greater than required, on average, in Canada as a whole. The grant would account for disparities in both tax capacity as well as fiscal need (e.g., provincial differences in the amount of poverty, provincial differences in the numbers of students in the educational system, etc.). The Rowell-Sirois Report also addressed the question of national standards but opposed them, arguing that imposition of national standards represented an unwarranted intrusion into provincial jurisdiction.

Although these recommendations of the Rowell-Sirois Report were never acted upon directly, the national government did accept some of the basic principles enunciated, and it eventually began to address the problem of unequal fiscal capacity. The Tax Rental Agreements of the 1940s and early 1950s were designed to incorporate an element of equalization. Then, in 1957, the national government introduced a formal equalization program to address disparities in tax capacities.

We have considered the Canadian system of equalization payments in detail elsewhere (Hum \& Strain 1984). Here, we merely note three features of the program which perpetuate horizontal inequities in Canadian social programs. First, the formula only adjusts for differences in tax capacities. No account is taken of disparities in fiscal need, thus there is no provision to increase the flow of funds to provinces where expenditure demands are relatively high. Second, the program does not "equalize" tax capacity. Rather, it brings the poorer provinces up to a specific standard (after 1982 this was a standard set by five Canadian provinces). Consequently, richer provinces still enjoy the capacity to provide their citizens with better services or lower taxes. Finally, the program is under the exclusive control of the national government, which finances it out of its own revenues. This is especially significant in an era of restraint when, for example, Ottawa decides to limit the growth in payments. In effect, the equalization formula is overridden whenever the formula requires payments above the specified maximum. 
The general equalization program, then, is not sufficient to assure horizontal equity in social policy. It cannot incorporate national standards (because it is an unconditional transfer); the formula fails to account for differences in fiscal needs; it does not truly "equalize" tax capacity, and it is vulnerable to ad hoc changes.

The inadequacies of the equalization formula as an instrument for horizontal equity could be addressed, in principle, through changes in other transfer programs designed to finance specific social programs. This is the conclusion of another study which addressed the horizontal equity issue in examining the Canada Assistance Plan (Hum 1983). The following sections of this paper illustrate how the Established Program Financing provisions for post-secondary education might be altered to achieve horizontal equity, but before turning to the EPF, we summarize the approach taken by Hum.

The Canada Assistance Plan is a 50/50 cost-sharing arrangement covering a variety of provincial general assistance and personal social service programs. There is substantial variation in the treatment of Canadians across provinces. For example, in 1980 general social assistance payments for a family of four ranged from a low of $\$ 6,400$ in Nova Scotia to a high of $\$ 10,500$ in Alberta. Hum argues that two changes would have to be made to CAP to redress horizontal inequities. First, the Plan would have to specify a minimum national standard, a standardized basic allowance. Second, the Plan must incorporate an adjustment to account for variation in tax capacity and fiscal need. This adjustment would then assure that a poorer province could afford to participate in the program without penalizing its citizens through higher taxes, or poorer services in other areas, or both.

The details of the suggested amendment are relatively straightforward. Since the tax burden imposed by a program which incorporates a standardized basic allowance is sensitive to two factors - the total cost of the program and the provincial tax base available to finance it - an adjustment incorporating both these factors is necessary. Conveniently, a simple "needs index" responsive to the number of poor requiring assistance, the extent of their poverty, and incomes (including natural resource revenues) generated in the province provides all the requisite information. If this index were introduced into the CAP cost-sharing formula, provinces with extensive poverty and/or a small tax base would receive more support than provinces not suffering these liabilities.

A similar index is used in our analysis of the EPF provisions for post-secondary education in the last section.

\section{Financing post-secondary education in Canada}

Although post-secondary education falls within the constitutional jurisdiction of the provinces, this has not kept the national government from financial participation in this field. Indeed, about 80 percent of provincial operating grants to universities and colleges are now financed by the national government. What is the rationale for financial involvement by the national government? Is it merely a 
convenient ploy to by-pass the restrictions of a constitution which placed education in the hands of the provinces? If so, is horizontal equity an issue?

Prior to 1945, the federal government was a minor player. Universities and colleges operated under provincial charter, relying heavily on tuition fees, private donations, and bequests for funds. Federal participation was limited to two very small cost-shared programs covering agricultural education and occupational training.

The Veterans Rehabilitation Act, 1945, increased national involvement in post-secondary education dramatically. This legislation gave bursaries to over 50,000 veterans, enabling them to attend university at little or no cost to themselves. It also provided direct grants to universities in recognition of the fact that student fees accounted for only about 40 percent of revenue. These funds were a welcomed source of money for Canadian universities but eventually evaporated with the inevitable decline in the number of veterans enrolled.

The noteworthy feature of this early incursion into post-secondary education is its underlying rationale. The bursaries and grants distributed under the Veterans Rehabilitation Act were not motivated by a concern for universities per se. Rather, the intent was simply to support the education of a specific group of Canadian citizens.

The emphasis on students and student aid changed with the Report of the Royal Commission on National Development in the Arts, Letters, and Science (the Massey Commission) in 1951. The Massey Commission, in keeping with its overall concern with cultural awareness and national identity, adopted a social utility view of post-secondary education. It acknowledged the economic contribution of universities and students, but it did not emphasize them. Instead, the universities' role in the development of national culture, science, and our understanding of ourselves as a people was highlighted. Consequently, the Commission recommended grants to support the work, broadly defined, of Canadian universities. The focus had shifted from educating students to fostering national institutions.

Shortly after the Commission's report was tabled in the House of Commons, the Prime Minister announced that "The government has ... reached the conclusion that it is in the national interest to take immediate action to assist universities to perform functions which are quite essential to the Country."

The national government introduced a program of direct grants to universities to achieve its objectives. The provinces, particularly Quebec, objected to this arrangement since it involved direct transfers rather than indirect and unconditional transfers through the provinces. However, the arrangement was continued, with an adjustment which affected only Quebec, until 1967.

The actual distribution of funds to universities and colleges was based on a two-tier formula. The formula first established provincial pools using a per capita transfer ( $\$ .50$ in 1951 , increasing to $\$ 5.00$ in 1966). Then the provincial pools were allocated to institutions within each province on the basis of enrollment. 
The new arrangements undoubtedly reflected new national government objectives. The Veterans Rehabilitation Act had established portable student bursaries and grants to support a specific group of Canadian students. This system could have been expanded to include a wider target population. However, a system of portable bursaries and grants would not have guaranteed the development of strong institutions in each province. A transfer which incorporated the provinces explicitly (as was done with the introduction of provincial pools) was thought necessary. ${ }^{2}$ Also, the fact that education remains a provincial responsibility doubtlessly influenced the design of the new program.

Unlike the Veterans Rehabilitation Act and similar student based aid programs, the new arrangement focused on post-secondary institutions and assured the continued development of these institutions in each province. This approach helped institutions in the poorer provinces which, due to chronic underfunding, would have had difficulty attracting students and student-based federal funding.

The underlying objective of the 1951 program to encourage the development of a strong and effective post-secondary education system across the country remains an explicit goal of national government. Moreover, the approach adopted in 1951 is similar to that used today, with the important difference that the per capita transfer now goes to the provincial governments, who are free to spend it in any way they choose.

The current system of unconditional per capita transfers evolved from changes first announced at a federal provincial conference in October 1966. After 1966, the national government began to transfer funds to the provinces rather than directly to universities. This arrangement involved an abatement of four equalized percentage points of personal income tax and one equalized point of corporate income tax, plus an adjustment payment to bring the total transfer up to 50 percent of allowable operating costs of post-secondary education, or $\$ 15.00$ per capita, whichever was greater.

The changes announced in 1966 increased the flow of funds to post-secondary institutions, although now through the provincial governments. However, because the new transfer was based on a matching formula, it incorporated all the basic design flaws typified by the 1927 Old Age Pension Plan - the traditional " $50 / 50$ matching formula". And in the absence of "full equalization", provinces which have a relatively high demand for post-secondary education, or a relatively small. tax base, will be forced to impose higher tax rates or provide poorer services in other areas, ${ }^{3}$ if they are to maintain national standards in post-secondary education. But the transfer does not provide incentives to maintain national standards. Consequently, the quality of post-secondary education varies widely across provinces.

In the 1970 s this transfer program came under attack, but not because of the basic design flaws discussed above. Instead, criticism arose for other reasons. The federal government, faced with growing deficits, wanted more control over its own spending. The provinces, too, were unhappy. They argued the scheme 


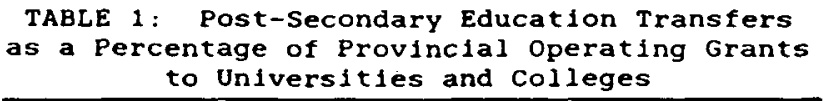

\begin{tabular}{|c|c|c|c|}
\hline \multirow[b]{3}{*}{ New found l and } & \multirow{2}{*}{\multicolumn{2}{|c|}{$\begin{array}{l}\text { Transfer as a } * \text { of } \\
\text { Operating Grants } \\
\begin{array}{ll}1977-78 & 1984-85\end{array}\end{array}$}} & \multirow[t]{2}{*}{$\begin{array}{c}\text { Reduction in Purely } \\
\text { Provincial Share }\end{array}$} \\
\hline & & & \\
\hline & $83.3 x$ & $106.9 \%$ & $23.9 \%$ \\
\hline P. E. I. & $101.5 x$ & $106.9 \%$ & $5.3 \%$ \\
\hline Nova Scotia & $87.5 \%$ & $91.6 \%$ & $4.1 \%$ \\
\hline New Brunswick & $98.1 \%$ & $101.8 \%$ & $3.7 \%$ \\
\hline Quebec & $56.1 \%$ & $59.6 \%$ & $3.5 \%$ \\
\hline ontario & $73.7 \%$ & $88.7 \%$ & $15.0 \%$ \\
\hline Manitoba & $80.3 \%$ & $102.9 \%$ & $22.5 \%$ \\
\hline Saskatchewan & $81.6 x$ & $90.3 \%$ & B. $7 \%$ \\
\hline Alberta & $63.9 \%$ & 73.18 & $9.2 \%$ \\
\hline British Columbia & 78.98 & 104.38 & $25.4 \%$ \\
\hline Canada & $68.9 \%$ & $79.6 \%$ & $10.7 \%$ \\
\hline
\end{tabular}

Source: A. W. Johnson: Giving Greater Polnt and Purpose to the Federal Financing of Postsecondary Education and

Research In Canada lottawa: Secretary of State. 1985)

distorted provincial planning in an area within provincial jurisdiction. These factors influenced the development of the 1977 transfer scheme.

This new transfer scheme was incorporated in the Established Program Financing (EPF) sections of the 1977 Federal Provincial Fiscal Arrangements Act. The EPF represented a major shift in the financing of three important cost-shared programs: hospital insurance, medicare, and post-secondary education. Although the new transfer scheme was based on an extremely complex formula, it was, in essence, a straightforward unconditional per capita grant (the hospital insurance and medicare provisions did have some strings attached). The transfer was made partly in cash, and partly through a transfer of tax points. It was designed to grow over time at about the rate of growth of Gross National Product. Since the grant was allocated on a per capita basis it was like the 1951 transfer to universities. That is, it was not related to the demand for post-secondary education, nor fiscal need. 
Moreover, because the grant was unconditional it was also not linked to provincial spending on post-secondary education; that is, provinces could spend the money in any way they chose. This last feature has been subject to extensive criticism (see below).

In 1982, new legislation simplified the EPF arrangement. The transfer became a straightforward per capita grant escalated at the rate of GNP growth. In 1984 the EPF legislation was amended and re-titled the Federal Provincial Fiscal Arrangements and Federal Post-Secondary Education and Health Contributions Act, 1977. The GNP escalator was changed for 1983-84 and 1984-85 to keep expenditures consistent with the national government's " 6 and 5" program. Michael Wilson's 1985 budget continued this restraint policy by limiting increases in transfers to the rate of growth of general government expenditures.

As noted above, the unconditional nature of the fiscal transfer has attracted criticism. In 1977, federal cash and tax point transfers comprised about 70 percent of provincial government operating grants to universities. By 1985, this proportion had increased to 80 percent. As the recent Macdonald Commission noted:

This situation has led to accusations that the provincial governments have been diverting to other uses large sums that Parliament intended to be spent on PSE. As a result many people, both inside and outside post-secondary institutions, have expressed concern that the EPF mechanism may not offer the most appropriate means of providing future federal support for post-secondary education.

The consequences of the unconditional nature of the transfer are illustrated in Table 1 which clearly indicates that the provinces have reduced their commitment to post-secondary education. ${ }^{4}$ This is a serious problem with the current arrangements. However, it is not the only problem. We now argue that the current EPF transfer is unlikely to achieve horizontal equity, the second of Canada's declared objectives in supporting post-secondary education.

A national program of direct portable grants to students is consistent with the horizontally equitable treatment of students. An institutional based funding program like the EPF, on the other hand, rarely achieves horizontal equity. Instead, horizontal equity must be achieved through careful design.

There are a number of proposals which advocate student-based funding as an alternative to current EPF arrangements. The underlying assumption is that support for post-secondary institutions is provided, primarily, to underwrite teaching costs and thus education of students. However, this ignores the first declared objective of national government policy: the development of a strong post-secondary education system across the country. Under direct student aid, students determine the distribution of funds by their choice of institution and these choices cannot guarantee the development of strong institutions in each province (see Note 2).

Why is the development of post-secondary institutions in each province even an objective of government policy? Is not the best education, regardless of where it is acquired, sufficient? The answer, in part, is that post-secondary institutions 
TABLE 2: Disparities in Post-Secondary Education, 1966

\begin{tabular}{lccc} 
Province & $\begin{array}{c}\text { Expenditure } \\
\text { Per Student }\end{array}$ & $\begin{array}{c}\text { Prov. Expenditure } \\
\text { Per Student }\end{array}$ & $\begin{array}{c}\text { Fed. Expenditure } \\
\text { Per Student }\end{array}$ \\
\hline Nfld. & 1516 & 658 & 314 \\
P. E. I. & 2057 & 306 & 233 \\
N. S. & 3068 & 950 & 164 \\
N. B. & 2575 & 758 & 196 \\
Que. & 2341 & 1177 & 245 \\
Ont. & 3837 & 2287 & 179 \\
Man. & 2423 & 998 & 180 \\
Sask. & 2827 & 1492 & 203 \\
Alb. & 3639 & 2387 & 165 \\
B. C. & 2776 & 1188 & 210 \\
Canada & 3046 & 1562 & \\
S & & &
\end{tabular}

Note: Quebec received a tax abatement equal to one corporate income tax point in ileu of the transfer

Sources: S. Petchinis: Financing Postseccondary Education in Canada (Toronto: Council of Ministers of Education, 1971) and Statistics Canada Education in Canada, Cat. No.

provide additional benefits to the public, and these benefits, emphasized by the Massey Commission, vary with space. Thus, to ensure that all Canadians may enjoy these benefits, the maintenance of strong institutions in each province is necessary. In the jargon of economics, universities are partly public goods, whose benefits decline with distance from the location of the institution.

It is important to recognize that there are two, analytically distinct, types of decisions which are made with respect to post-secondary education. Decisions are made by individuals when procuring or buying their education, and decisions are made by institutions (or society) for providing or selling that education. Individual decisions are based on an assessment of the costs and benefits of alternatives, so individuals do what they consider best for them. Institutional decisions, on the other hand, are more complex, especially when made on behalf of society. For one thing, the time horizons relevant to the two types of decisions are different. Moreover, institutional decisions often involve social choice considerations. The 
TABLE 3: Provincial Operating Grants to Universities Per Full Time Equivalent Student

$1983-84$

\begin{tabular}{|c|c|c|}
\hline Province & $\begin{array}{l}\text { Grants Per Full } \\
\text { Time Equivalent }\end{array}$ & $\begin{array}{c}\text { AS A } \% \text { of } \\
\text { National Average }\end{array}$ \\
\hline Nf $1 d$. & 8909 & 136.1 \\
\hline P. E. I. & 5796 & 88.5 \\
\hline N. S. & 5637 & 86.1 \\
\hline N. B. & 5629 & 86.0 \\
\hline Que. & 7345 & 112.1 \\
\hline Ont. & 5581 & 85.2 \\
\hline Man. & 6075 & 92.8 \\
\hline Sask. & 6519 & 99.6 \\
\hline Alb. & 8266 & 126.1 \\
\hline B. C. & 7765 & 118.6 \\
\hline Canada & 6548 & \\
\hline
\end{tabular}

Source: Secretary of State. Support For Postsecondary Education

In Canada, 1977-1985

goal of a strong and effective post-secondary system across the country undoubtedly reflects the wishes of Canadians as a society.

However, the two types of decisions must be complementary. If mobile students, as a result of their choices, do not distribute themselves in a way which complements the distribution of institutional transfers, problems will emerge. For example, if, as is the case with the EPF, funds are distributed on a per capita basis, universities and colleges in provinces which educate more than their share of students (the appropriate share is taken as the provincial population divided by the national population) will receive less funding per student than institutions in provinces which attract less than their share of students. This is not horizontally equitable.

Thus, a post-secondary transfer to be horizontally equitable must recognize complementarity. But this is not all. As emphasized in our discussions of the 1927 Old Age Pension Plan and the Canada Assistance Plan, it is also necessary to account for differences in tax capacity and fiscal need. Otherwise, provinces will have to impose very different tax burdens to provide the same standard of education, or standards will vary due to differences in ability to pay. 


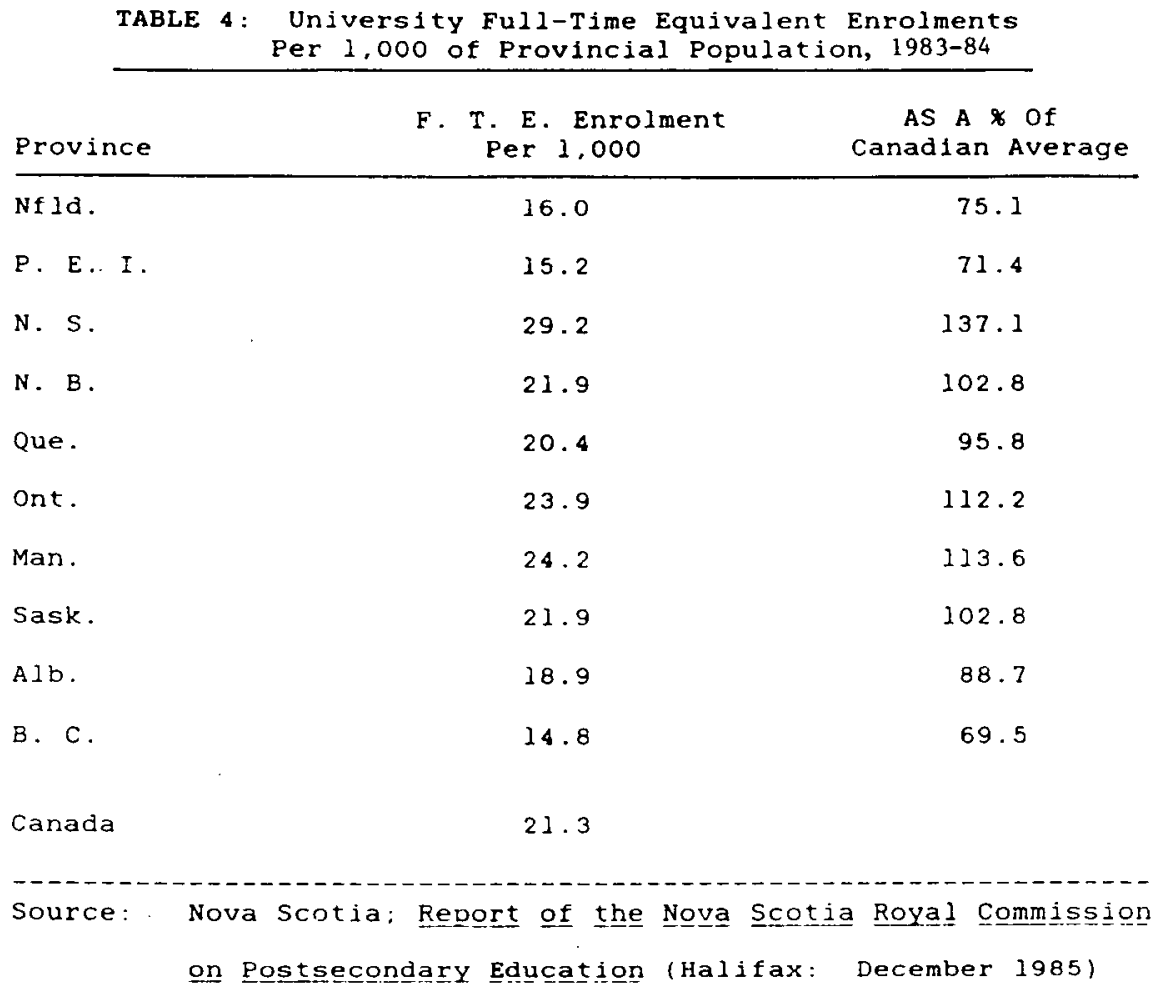

The consequences of ignoring these three factors - complementarity, fiscal need, and tax capacity - are evident in Table 2, using data generated by the transfer program first put in place in 1951. Because the 1951 program involves direct grants to universities, provincial diversion of funds (portrayed in Table 1) does not arise. Consequently, the data allow us to focus on complementarity and differences in fiscal need and tax capacity.

Table 2 clearly illustrates disparities in the post-secondary education system in 1966, 15 years after the 1951 program was introduced. Poorer provinces were unable to provide grants to their universities and colleges as large as those provided by the richer provinces, and disparities in expenditure per student was the result. Furthermore, variation in federal transfers illustrates the consequences of ignoring complementarity. Universities and colleges in some provinces (for example, Nova Scotia) are twice penalized. Not only is their provincial government unable to provide funding at national levels, but they are also educating more than the province's share of students. (Table 4 gives the distribution of students.)

The disparities under the current EPF arrangement are illustrated in Table 3. Although the details of the disparities have clearly changed, the absence of national standards is still quite evident. 


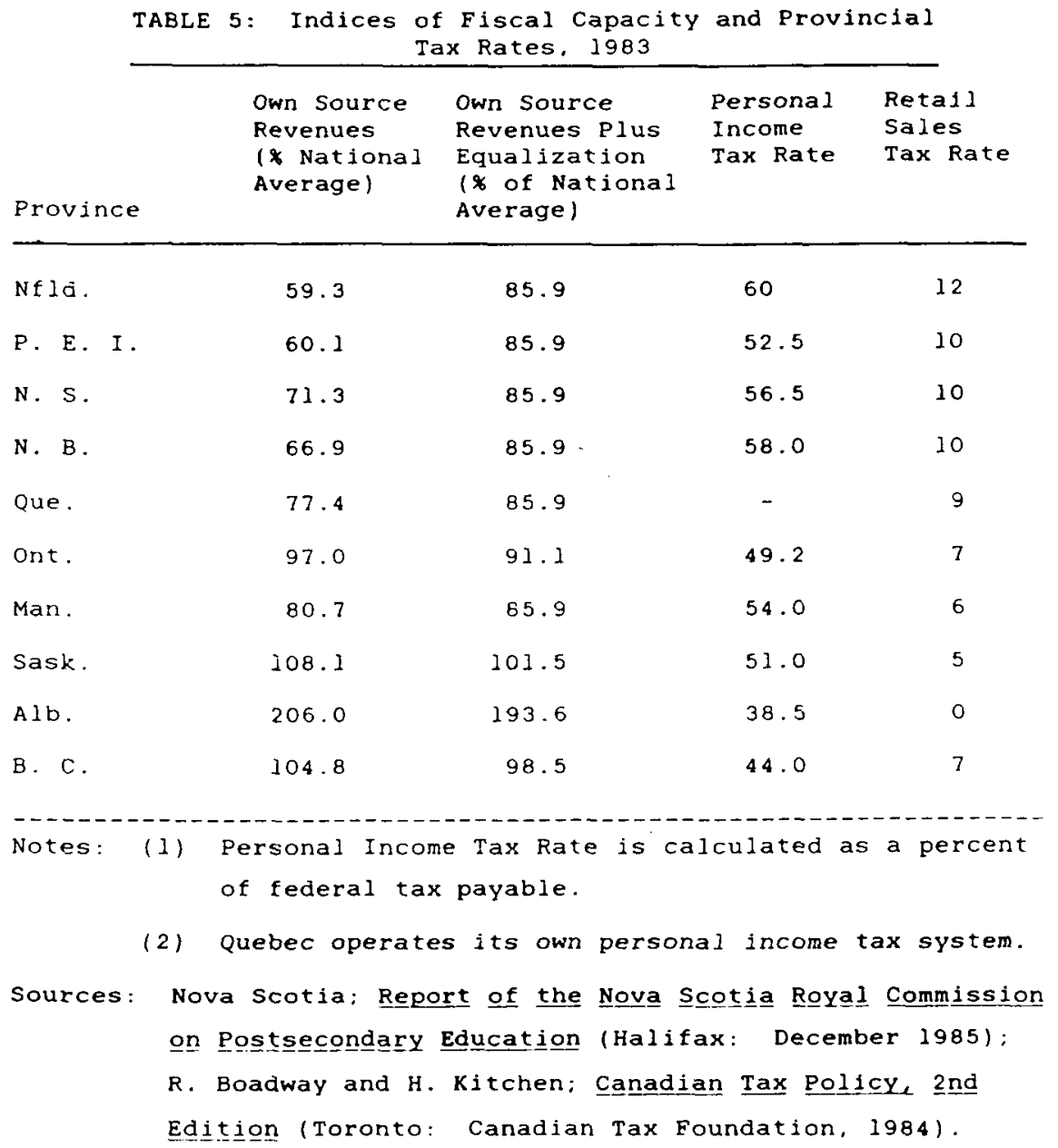

Table 6 provides an indication of government commitment to postsecondary education.

Variation in operating grant per student undoubtedly reflects differences in provincial priorities. However, absence of adjustment in the EPF for the distribution of students and difference in fiscal need and tax capacity also play a critical role. Table 5 presents some of the variation in fiscal capacity and tax rates. The high tax rates and low fiscal capacity, even after equalization, in the poorer provinces indicate the inadequacy of the current equalization formula. Examination of Tables 4 and 5 reveals the importance of fiscal need and tax capacity and the distribution of students. Inferences drawn from these tables are reinforced by Table 6. 
TABLE 6: Indicators of Government Support for Universities $1982-83$

\begin{tabular}{|c|c|c|}
\hline Province & $\begin{array}{c}\text { Total University operating } \\
\text { Expenditures As } \% \text { of } \\
\text { Provincial GDP }\end{array}$ & $\begin{array}{l}\text { Provincial Operating } \\
\text { Grants Per } \$ 1,000 \\
\text { of Personal Income. }\end{array}$ \\
\hline$N f \perp d$. & 1.69 & 14.16 \\
\hline P. E. I. & 1.15 & 11.49 \\
\hline N. S. & 2.05 & 14.24 \\
\hline N. B. & 1.59 & 13.25 \\
\hline Que. & 3.42 & 13.11 \\
\hline Ont. & 0.94 & 8.18 \\
\hline Man. & 1.17 & 11.14 \\
\hline sask. & 1.13 & 10.05 \\
\hline Alb. & 0.91 & 11.14 \\
\hline B. C. & 0.93 & 9.24 \\
\hline Canada & 1.11 & 10.39 \\
\hline Source: & $\begin{array}{l}\text { Ontario Ministry of Colleges and } \\
\text { of Ontario Universities, Triparta } \\
\text { Provincial Comparisons. Interpro }\end{array}$ & $\begin{array}{l}\text { Universities, Council } \\
\text { ate Committee on Inter- }\end{array}$ \\
\hline
\end{tabular}

A quick comparison of Tables 3 and 6 reveals a number of paradoxes. For example, Nova Scotia, New Brunswick, Prince Edward Island, and Manitoba provide support per student much lower than the national average. Yet government support and total expenditure per dollar of provincial product in these provinces are above the national average. At the same time, British Columbia and Alberta institutions enjoy larger than national average grants per student, but require a smaller than national average portion of gross provincial product to do so. The explanation for those apparent paradoxes lies in the data presented in Tables 5 and 6.

To conclude, the current EPF arrangement has a number of fundamental design flaws. First, the transfer is unconditional. Second, absence of adjustment to account for the distribution of students across provinces penalizes provinces attracting more than their share of students. Finally, an inadequate equalization program leaves some provinces without the fiscal ability to support national 
expenditure standards. These problems can be addressed by adopting a formula financing scheme similar to that suggested by Hum for the CAP. This scheme, and a number of other reform proposals, are now examined in more detail.

\section{Horizontal equity and a needs adjusted EPF Transfer}

There are a number of possible reforms to the current EPF program as it relates to post-secondary education. As previously noted, direct funding of students is consistent with the horizontal equity principle as well as the assumption that support for post-secondary education is provided primarily to underwrite teaching costs. The recent Macdonald Commission urged this proposal. Since direct funding of students would distribute federal monies across Canada on the basis of student population rather than provincial population, there would be significant interprovincial dollar shifts if the current per capita formula were replaced by direct-to-student grants. Table 7 indicates the extent of changes from replacing the current EPF program by direct student funding. The Macdonald Commission appears unsympathetic to the generalized "public good" feature of universities and colleges beyond its specific research outputs. The external benefits which accrue to society from the non-teaching activities of universities require that some portion of operating expenses be financed by government grants. Obviously there can be wide disagreement concerning the appropriate shares of operating costs to be borne by student fees and government grants. Rosenbluth and Scott (1981) "guess" that fees should finance approximately 25 percent of university operating costs while government grants should finance the remainder. Whatever the proportions, many are persuaded that a significant fraction of operating costs must be directed through non-fee channels; hence the question of a horizontally equitable intergovernmental transfer formula.

The recent Johnson Report (1985), mindful of charges that provinces were diverting funds from post-secondary education purposes, recommended a scheme of incentive grants. Unlike the Macdonald Commission, it did not favour direct student funding. The Johnson reform proposal would grant monies to provinces for a particular program, but also contain incentive provisions whereby increases in provincial expenditures in the PSE area would attract additional federal grants. The Johnson Report proposals would go a long way towards addressing certain of the fundamental flaws already noted; particularly the totally unconditional nature of the current EPF transfer. However, it does not adequately advance the objective of horizontal equity. This latter goal can only be effected through a needs-adjusted formula.

Two principles underlie the rationale for a needs-adjusted EPF transfer. The first principle is that citizens in each province should be able to secure benefits provided by local post-secondary institutions. This requires not only assuring access by students to post-secondary education of comparable standard, but also access by citizens in general to the public goods and services provided by post-secondary institutions (libraries, research, heritage and culture, etc.). The second principle is that citizens in each province should have to make about the 
same sacrifices (reduced consumption of other goods) to secure these PSE benefits. To meet this objective, fiscal transfers must assure that citizens in each province face about the same tax rate when securing about the same benefits.

Concern with access and quality throughout the country can be addressed by incorporating an expenditure 'standard' into the EPF transfer formula. The expenditure standard, like the standardized basic allowance in Hum's work on the CAP, would be a base amount negotiated in advance. An obvious candidate for this standard is the Canadian average expenditure per student. However, any standards might be negotiated. For example, the per student expenditure in a particular province, or the average expenditure per student of a subset of provinces are also possibilities. The choice of standard should reflect one's view of the expenditure needed to assure post-secondary education of appropriate quality.

The provincial tax burden of a program which incorporates an explicit per student expenditure standard would be sensitive to the number of post-secondary students in that province, as well as the provincial tax base of that province. Accordingly, these factors should be included in the adjustment. Conveniently, a simple index incorporating the requisite information can be defined to calculate the appropriate adjustment. ${ }^{5}$

The basic rationale underlying the suggested adjustment may be conveniently summarized by the correction factor to be applied to each province:

$$
\mathrm{T}(\mathrm{E})=\frac{\mathrm{N}(\mathrm{E}-\mathrm{u})}{\mathrm{PY}}
$$

Suppose it is determined that the amount $\mathrm{E}$ is the appropriate average expenditure per student necessary to maintain the desired standard. Suppose, further, that $u$ is the average expenditure per student that a province can afford to spend in the absence of fiscal transfers. The amount $(E-u)$ is the expenditure shortfall per student; hence, if $\mathrm{N}$ is the number of full-time undergraduate equivalents, the total expenditure shortfall for the province is $\mathrm{N}(\mathrm{E}-\mathrm{u})$. This is the numerator. However, this shortfall must be viewed alongside the province's population, $\mathrm{P}$, and its per capita revenue from all sources, $Y$. This is the denominator. Accordingly, the ratio $T(E)$ indicates precisely that the necessary correction is dependent on the choice of $\mathrm{E}$; it is also directly proportional to the cost factors $\mathrm{N}$ and $(\mathrm{E}-\mathrm{u})$, the number of full-time equivalent students and the expenditure shortfall respectively; and inversely proportional to the population and fiscal potential (wealth) of the province. This index or correction factor has the following convenient interpretation. Once the expenditure standard, E, is defined, $T(E)$ is the tax rate that would have to be imposed on the average citizen in order to meet the requisite expenditure standard for education, the "need" in this case. Obviously, there is still wide scope in defining $\mathrm{E}, \mathrm{Y}$, and the notion of full-time undergraduate equivalents. These are practical problems and many variants to measuring income, full-time equivalents, etc. can be accommodated in the suggested formula.

For example, should the expenditure standard reflect differences in program costs? The cost of educating a science student is generally higher than that for an 
Table 7. Interprovincial Shifts of EPF Payments: Macdonald Proposal and Needs-Adjusted Formula

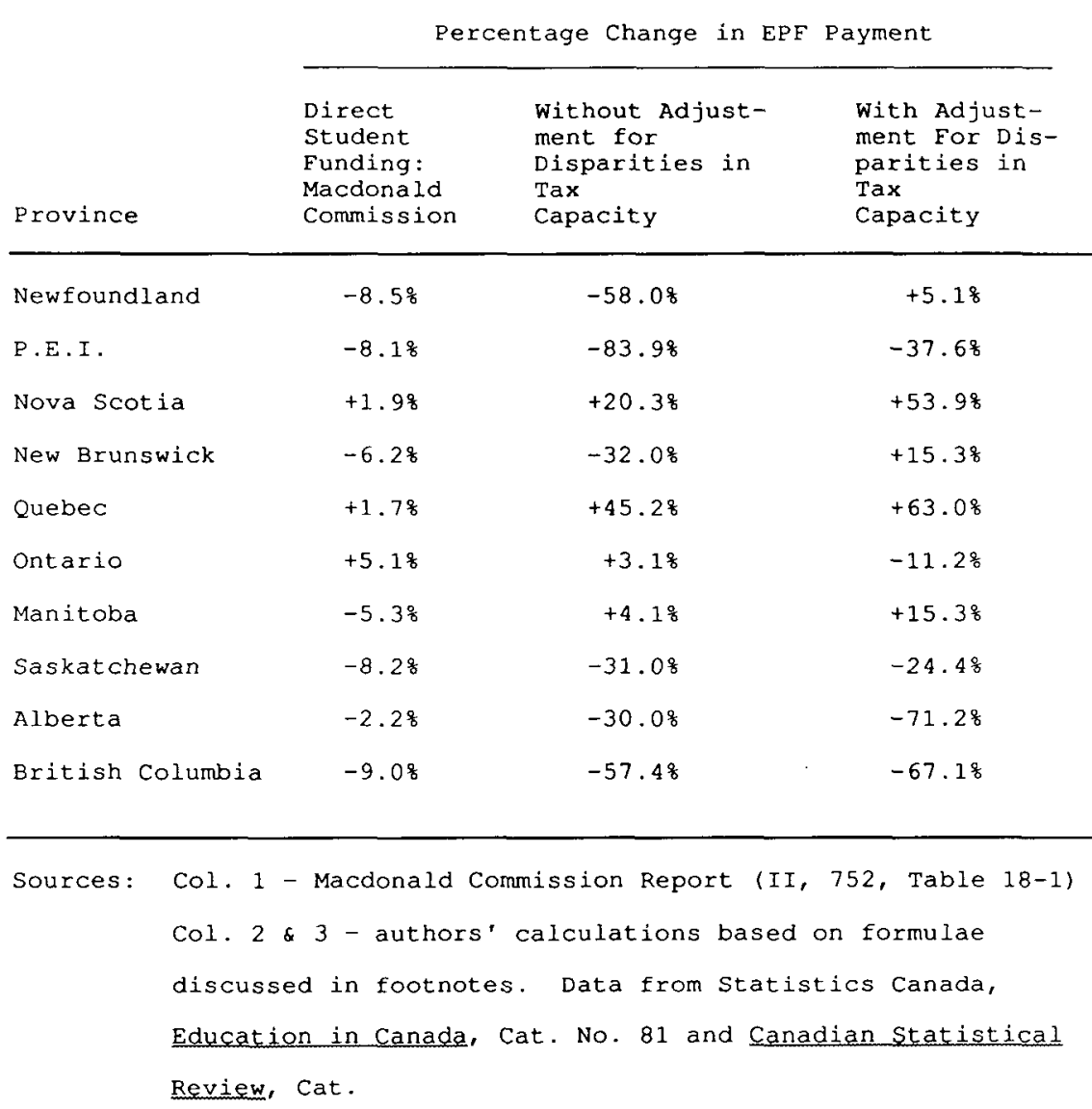

arts student; graduate programs are more expensive than undergraduate programs; etc. We shall choose, as an illustrative expenditure standard, the Canadian average expenditure per student, but adjusted for differences in education costs across five broad groups of students, namely CEGEP students in Quebec, full-and part-time undergraduate university students, and full- and part-time graduate university students. Cost differences are thus captured by measuring enrollments using a full-time undergraduate equivalency. ${ }^{6}$

There are also practical problems due to differences in tax base. For example, one could assume, for the purposes of program design, that the equalization program had already effectively equalized tax capacity. With this assumption no adjustment for tax capacity would be necessary. This possibility is illustrated above in Table 7 , second column. ${ }^{7}$ On the other hand, without assuming that tax bases are equalized beforehand, the problem of defining the tax base remains. One 
might then either define a representative tax system, the current approach of the Department of Finance, or, alternatively, employ a measure of adjusted provincial income, such as that used in recent work by Davenport (1984). ${ }^{8}$ We employ the Davenport approach when making our adjustments for tax capacity in the EPF formula. ${ }^{9}$

The changes in the distribution of the EPF post-secondary education budget which result when either of the two different needs adjustments is used are displayed in Table 7, columns 2 and 3. The actual EPF payment in 1983-84 was $\$ 159.91$ per person. Table 7 clearly indicates that substantial changes are required if the EPF transfer were to be made consistent with the principles enunciated in this paper.

The Province of Quebec would be the largest beneficiary of our suggested changes, simply because that province educates a larger portion of its population than any other. Nova Scotia and Manitoba would also gain, but Saskatchewan, Alberta, and British Columbia would be big losers. Interestingly, Prince Edward Island would also be a loser; this is a consequence of the large number of Islanders who go elsewhere for their post-secondary education.

The changes imposed on other provinces depend on the adjustment formula adopted. Not surprisingly, Newfoundland and New Brunswick gain when account is taken of differences in adjusted provincial income. Under this adjustment Ontario loses. However, when there is no adjustment for tax capacity, Ontario gains due to the large number of students there, while New Brunswick and Newfoundland lose.

But whatever the particular details of a needs-adjustment formula, it is abundantly clear that reform of the EPF transfer for PSE is overdue, and the disparities and fragmented social welfare structure of this country can only be eliminated by reforms that are dictated by horizontal equity objectives.

\section{NOTES}

1 One approach to resolve this political debate is to introduce the notion of primary citizen rights in a federal state and to draw upon an explicit normative framework. This perspective is discussed by Strain and Hum (1987) who point out that Paretian welfare economics, an approach which emphasizes the responsiveness of policy to the preferences of the electorate, favors a decentralized federal state. Thus Paretian welfare economics would support the view that horizontal equity is important only within a province. However, we also note that arguments by philosophers such as John Rawls support the opposite position; namely, that horizontal equity is a general principle, and should therefore apply regardless of the constitutional assignment of powers. Our view is that neither legal positivism nor normative political philosophy can settle the question once and for all.

2 One reviewer queries why incorporating provinces explicitly is necessary to guarantee strong institutions. The underlying model is the neoclassical theory of choice, suggesting that students will choose to go to the strongest (richest) institutions, all things equal. Declining enrollments lead to decreasing income for poorer institutions. With less income, these institutions find it harder to attract students, etc. The dynamic suggested is: nothing succeeds like success, and nothing fails like failure. Support through channels other than purely direct student support is therefore necessary to assure a balanced development of institutions to enable students to choose among roughly equal institutions. 
3 The $\$ 15$ per capita amount may be seen as a floor to the level of services that can be provided. Still, there is no incentive to maintain standards.

4 One reviewer takes us to task for our too-ready acceptance of the federal position in dividing the total EPF transfer among the programs in the proportions prescribed by the federal government. Further, the reviewer questions the interpretation of the tax portion. With much respect, these perennial issues are continuing controversies and both 'federal' and 'provincial' positions are well known. We choose not to enter this debate here. The substantive argument of our paper is not affected by different apportioning ratios of the EPF transfers. We regard our reform proposal as suggestive rather than definitive and if Canada and the provinces were to agree on a different prorationing rate, we would simply re-do the arithmetic. However, each province undoubtedly has a different view of how the EPF transfer should be apportioned in their province. In a sense, we adopt the federal numbers for the pragmatic reason of getting a consistent set of numbers for our illustration.

5 The needs index used derives from Kakwani (1980). He defines the needs index, $P(X)$, as (N/P) $(\mathrm{X}-\mathrm{u}) / \mathrm{U}$ where $\mathrm{N}$ is the number of beneficiaries (e.g., poor below the poverty line; $\mathrm{P}$ is population; $\mathrm{U}$ is mean income; $\mathrm{X}$ is the expenditure standard (poverty line); $\mathrm{u}$ is the pretransfer consumption (income) of the average beneficiary. This needs index has an attractive interpretation: it is the tax rate that would have to be imposed on the average citizen to eliminate needs. See Hum (1983) for an application to the CAP program.

6 Undergraduate full-time equivalent enrollment is calculated by assuming that (1) each part-time undergraduate student is equivalent to 0.4 full-time undergraduate; (2) each graduate student is equivalent to four full-time undergraduates; and (3) each CEGEP student is equivalent to 0.8 undergraduate. The adjustments exclude community college enrollments.

7 The needs adjustment in this case is $t(i)=[N(i) / P(i) x-(N(c) / P(c)] x$, where $x$ is the Canadian average expenditure; $N(i)$ is the undergraduate full-time equivalent enrollment in province $i ; N(c)$ is undergraduate full-time equivalent enrollment in Canada; $P(i)$ is the population in province $i ; P(c)$ is the population in Canada.

8 The measure of adjusted provincial income developed by Davenport includes natural resource revenues and is designed to reflect the income available in each province for consumption. Davenport argues that it is a better basis for equalization than the representative tax system.

9 The needs adjustment in this case is $t(\mathrm{i})=[\mathrm{N}(\mathrm{i}) / \mathrm{P}(\mathrm{i})] \mathrm{x}-[(\mathrm{N}(\mathrm{c}) / \mathrm{P}(\mathrm{c}))(\mathrm{API}(\mathrm{i}) / \mathrm{API}(\mathrm{c})] \mathrm{x}$ where $\mathrm{API}(\mathrm{i})$ and $\mathrm{API}(\mathrm{c})$ are adjusted provincial income measures for province $\mathrm{i}$ and Canada respectively.

\section{BIBLIOGRAPHY}

Canada. (1939). Report of the Royal Commission on Dominion-Provincial Relations. Ottawa: King's Printer. (the Rowell-Sirois Report).

Canada. (1985). Post-Secondary Education in Canada. Ottawa: Secretary of State.

Canada. (1985). Report of the Royal Commission on the Economic Union and Development Prospects for Canada, Vol 2. Ottawa: Supply and Services Canada. (the Macdonald Report).

Davenport, P. (1982). "The Constitution and the Sharing of Wealth in Canada", Law and Contemporary Problems, Vol. 45, No. 4, 109-47.

Eggleton, C., \& J. Kraft. (1939). Dominion Provincial Subsidies and Grants. A Study prepared for the Royal Commission on Dominion Provincial Relations. Ottawa: King's Printer.

Hum, D. (1983). Federalism and the Poor: A Review of the Canada Assistance Plan. Toronto: Ontario Economic Council.

Hum, D., \& Strain, F. (1984). "Redistribution and Equalization in a Federal State: A Social Welfare Approach", Western Economic Review, 3, 49-65.

Johnson, A. W. (1985). Giving Greater Point and Purpose to the Federal Financing of Post-Secondary Education and Research in Canada. Ottawa: Secretary of State.

Maxwell, J. A. (1937). Federal Subsidies to Provincial Governments in Canada. Cambridge: Harvard University Press. 
Nova Scotia. (1985). Report of the Nova Scotia Royal Commission on Postsecondary Education. Halifax: Queen's Printer.

Petchinis, S. (1971). Financing Post-Secondary Education in Canada. Toronto: Council of Ministers of Education.

Rosenbluth, G., \& Scott, A. (1981). "The Role of Governments in the Funding of Universities", in D. Nowlan and R. Bellaire (Eds.) Financing Canadian Universities: For Whom and By Whom? Pp. 220-27. Toronto: OISE Press.

Strain, F., \& Hum, D. (1987). "Canadian Federalism and the Welfare State: Shifting Responsibilities and Sharing Costs", in J. Ismael (Ed.) The Canadian Welfare State: Evolution and Transition. Edmonton: University of Alberta Press. 